\title{
MINIMÁLIS KIMENETI TELJESÍTMÉNY MEGHATÁROZÁSA ENERGY HARVESTING PROTOTÍPUSHOZ: EGY ESETTANULMÁNY MOBILTELEFON SPECIFIKÁCIÓKRA
}

\section{APPROXIMATING THE MINIMUM OUTPUT POWER FOR ENERGY HARVESTING PROTOTYPE: A CASE STUDY OF CELL PHONE SPECIFICATIONS}

\author{
Afghan Syeda Adila ${ }^{1}$, Almusawi Husam², Geza Husi ${ }^{3}$ \\ University of Debrecen, Faculty of Engineering, Department of Electrical \\ Engineering and Mechatronics,4028, Hunagry, Debrecen, Ótemetö Street 2-4, \\ Telefon $+36-203-938197$ \\ ladila@eng.unideb.hu \\ asdsw@ymail.com \\ 3husigeza@eng.unideb.hu
}

\begin{abstract}
Micro-scale energy harvesting solutions are highly demanded globally in almost every field.Specifically, when it comes for a cell phone battery life. The imbalanced situation between battery technology and cell phone evolution is getting worse. However the efficient system is needed which is able to charge a cell phone when we are off from the power source.The researchers put forwards the attention towards the readily available energy sources to be harvested for charging purpose.For making such efforts, number of solutions have been proposed but many hurdles lies in it which includes the design, compatibility and most importantly the different parameters of every cell phone device.This paper demonstrates the specifications of different cell phone models and a datasheet is produced which includes the minimum output power requirement during standby and talk time.
\end{abstract}

Keywords: energy harvesting, renewable energy sources, micro-scale energy, energy harvesting modules.

\section{Összefoglalás}

A mikro mértékủ "energy harvesting" megoldásokra világszerte, szinte minden területen óriási igény van. Különösen, amikor a mobiltelefon élettartamát illeti, hiszen a használati követelmények nem megfelelően gondoskodnak a képességek szerinti technológiai fejlesztésekről. Ebben a kiegyensúlyozatlan helyzetben az akkumulátor technológia és a mobiltelefon fejlödése között hatalmas különbség van a tudományos kutatásokban is. Azonban egy hatékony rendszerre van szükség, amely képes a mobiltelefon töltésére akkor is, amikor messze vagyunk az áramforrástól. A kutatók figyelmet fordítanak a könnyen elérhető energiaforrásokra, amelyek töltési célokra "beszüretelhetőek". Az ilyen erőfeszítésekkel számos megoldás érhető el, de számos akadály is rejlik bennük, mint például a tervezés, a kompatibilitás és ami a legfontosabb, hogy minden mobiltelefon készülék különböző paraméterekkel rendelkezik. Ez a cikk bemutatja a különböző telefon modellek specifikációit, valamint egy adatlapot állít elö, amely meghatározza a minimális kimeneti teljesítmény követelményeket készenléti és beszélgetési időre vonatkozóan ideális körülmények között.

Kulcsszavak: energia szüret, megújuló energiaforrások, mikro-méretü energia, energy harvesting modulok. 


\section{Introduction}

Cell phone battery capacity creates a major challenge in the field of research and industrial domain. Considering the alternative solutions like increasing the battery size and providing power banks are not admired by the users [10].Energy harvesting devices are needed which are able to charge the cell phone any where any time without being bound to the power source.There are number of energy harvesting modules available that are taking power from ambient energy sources like Solar, Wind and Heat energy, but still its a long way to go for providing efficient solutions for cell phone charging [2-4].

\section{Energy Harvesting Prototypes}

\subsection{Solar Energy based Energy Harvesting Prototype}

This source is considered as the most powerful of all, as it is available in vast amount to charge the electronic devices.A low cost photovoltaic energy harvesting circuit was introduced which is able to operate constantly on solar panel's MPP in order to grant maximum amount of power[4]. A wireless technique suggested by another researcher by using optical wireless power transfer, consist of an optical antenna built in on a solar cell and a DC-DC conversion circuit. Author claims that the efficiency is 40 times more than the conventional solar charger [8]. Other than that Maximum Power Transfer Tracking ystems are upgraded with dynamic online programming system [9].

\subsection{Radio frequency based Energy Harvesting Prototype}

We are surrounded by radio frequency every time transmitted by communication systems [1,11]. A model proposed in which power generating circuits are used to extracts the radio frequency, in which a printed dipole antenna extracts the power from GSM900 and GSM1800[1]. As the retrieved power from radio frequency is very low so in order to enhance the power, different techniques are proposed like matching and rectifying circuit and voltage multiplying circuit, in order to charge the cell phone [11].

\subsection{Mechanical Energy based Energy Harvesting Prototype}

Human power is a viable source which can be used to charge cell phone devices, transformation can be extracted by piezo electric material. However, number of significant contributions are done like key pressing on cell phone [1], Hand crank generators [5], to name few. A prototype was also suggested named as Human Powered Contactless Charger for CellPhones (HCCC), the device includes a Human Power Harvester (HPH) and a Receiving Unit (RU) along with gears and clutch as shown in the Figure 1. The authors demonstrates the $1020 \mathrm{mAh}$ battery is being efficiently charged by the proposed model [7].

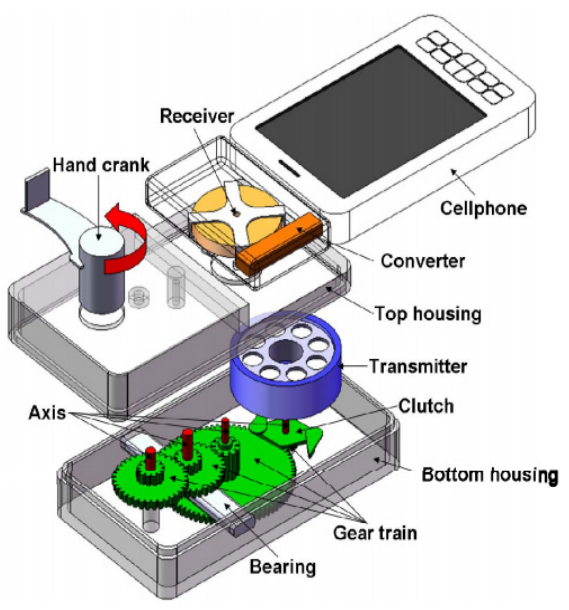

1.Figure. The Structure of HCCC 
a case study of cell phone specifications

\subsection{Hybrid Energy Harvesting Prototype}

Hybrid systems can collectively harvest multiple energy sources from the environment. Solutions have been provided in which a model combines the mechanical and piezoelectric techniques on a human shoe for extraction of human power. This system harvest the walking patterns by mechanical energy harvester and at the same time the exerted pressure which is produced by human weight is being harnessed by piezoe lectric system,Hence the converted power is able to charge a cell phone [6].

\section{Methodology}

\subsection{Cell Phone specifications as data requirement}

According to the research objective, the required data includes, Battery Capacity (mAh), Battery Potential (V). Battery Life during Stand By (h) and Battery life during Talk time (h).

For the calculation of the output power (mW) during Stand By and output power $(\mathrm{mW})$ during a talk time; following formulae are used.

Current (I):

$$
I=\frac{Q_{\text {battery }}}{t}
$$

Reference of the equation (1) Where $I$ is charging current, $Q_{\text {battery }}$ is battery capacity and $t$ denotes battery life.

Power (P):

$$
P=V \times I
$$

Reference of the equation (2) Where $\mathrm{P}$ denotes Power, V is battery potential and I is charging current.

An example has been taken under consideration of a cell phone model of Apple iPhone 7 along with the required input variables for the desired output.
To calculate required power during standby under ideal conditions we have the following specifications:

- Battery voltage $=3.7 \mathrm{~V}$

$-\mathrm{Q}_{\text {battery }}=1960 \mathrm{mAh}$

$-\mathrm{t}_{\text {standby }}=240 \mathrm{~h}$

$-\mathrm{t}_{\text {talk time }}=14 \mathrm{~h}$

To calculate the power $(P)$ value during standby, first we must need to know that how much current $(I)$ is required for charging purpose. These calculations are assumed to be ideal as we are not including the state of charge (SOC) for current (I) level of a battery cell.

1. table. Output Power $(P)$ during Stand by

\begin{tabular}{|c|c|}
\hline $\begin{array}{l}\text { Calculation } \\
\text { Current }(I) \\
\text { Stand by during }\end{array}$ & $\begin{array}{l}\text { Calculation of Power } \\
(\mathrm{P}) \text { during Stand by }\end{array}$ \\
\hline \multicolumn{1}{|l}{$=\frac{1960}{240}$} & $\begin{array}{l}P=3.7 \times 8.16 \\
=30.19 \mathrm{~mW}\end{array}$ \\
$=8.16 \mathrm{~mA}$ & \\
\hline
\end{tabular}

\begin{tabular}{|c|c|}
\hline $\begin{array}{lr}\text { Calculation } & \text { of } \\
\text { Current } \quad(I) & \text { during } \\
\text { Stand by } & \end{array}$ & $\begin{array}{l}\text { Calculation of Power } \\
\text { (P) during Stand by }\end{array}$ \\
\hline $\begin{array}{l}I=\frac{1960}{14} \\
=140 \mathrm{~mA}\end{array}$ & $\begin{array}{l}P=3.7 \times 140 \\
=518 \mathrm{~mW}\end{array}$ \\
\hline
\end{tabular}

2. table. Output Power $(P)$ during Talk time

The values are demonstrated in 1.Table and 2. Table for the charging current and output power in order to charge the specific cell phone during standby and talk time.

\section{Results and Conclusion}

The datasheet is produced as shown in Figure. 2 which shows the minimum output power required during standby and talk time for different cell phone models. These calculated values are the optimal ones which can be used for generic approximation in order to understand the power requirement. 


\begin{tabular}{|c|c|c|c|c|c|c|c|c|c|c|c|c|c|c|c|c|c|c|}
\hline S.No & Model & $\begin{array}{l}\text { Battery } \\
\text { Type }\end{array}$ & $\begin{array}{l}\text { Battery } \\
\text { Capacity }\end{array}$ & Unit & $\begin{array}{l}\text { Battery } \\
\text { Stand By }\end{array}$ & Unit & $\begin{array}{l}\text { Battery } \\
\text { Talk Time }\end{array}$ & Unit & $\begin{array}{l}\text { Current } \\
\text { for S.B }\end{array}$ & Unit & $\begin{array}{c}\text { Current for } \\
\text { T.T }\end{array}$ & Unit & Voltage & Unit & $\begin{array}{l}\text { Power Req: } \\
\text { during S.B }\end{array}$ & Unit & $\begin{array}{c}\text { Power Req: } \\
\text { duting T.T }\end{array}$ & \\
\hline 1 & iPhone 7 & Li ion & 1960 & mAh & 240 & h & 14 & h & 8.16667 & $\mathrm{~mA}$ & 140 & $\mathrm{~mA}$ & 3.7 & V & 30.2166667 & $\mathrm{~mW}$ & 518 & $\mathrm{~mW}$ \\
\hline 2 & Blackberry Priv & Li ion & 2610 & mAh & 576 & h & 17 & h & 4.53 & $\mathrm{~mA}$ & 153.53 & $\mathrm{~mA}$ & 3.7 & V & 16.77 & $\mathrm{~mW}$ & 568.06 & $\mathrm{~mW}$ \\
\hline 3 & $\begin{array}{l}\text { HuaweiAscend } \\
511\end{array}$ & Li ion & 1730 & mAh & 300 & h & 13 & h & 5.77 & $\mathrm{~mA}$ & 133.08 & $\mathrm{~mA}$ & 3.7 & V & 21.34 & $\mathrm{~mW}$ & 492.38 & $\mathrm{~mW}$ \\
\hline 4 & HTC 10 & Liion & 3000 & mAh & 456 & h & 27 & h & 6.58 & $\mathrm{~mA}$ & 111.11 & $\mathrm{~mA}$ & 3.7 & V & 24.34 & $\mathrm{~mW}$ & 411.11 & $\mathrm{mW}$ \\
\hline 5 & Galaxy Note 3 & Liion & 3200 & mAh & 420 & h & 21 & $\mathrm{~h}$ & 7.62 & $\mathrm{~mA}$ & 152.38 & $\mathrm{~mA}$ & 3.7 & V & 28.19 & $\mathrm{~mW}$ & 563.81 & $\mathrm{~mW}$ \\
\hline 6 & Sony Xperia Z3 & Li ion & 3100 & mAh & 890 & h & 14 & $\mathrm{~h}$ & 3.48 & $\mathrm{~mA}$ & 221.43 & $\mathrm{~mA}$ & 3.7 & V & 12.89 & $\mathrm{~mW}$ & 819.29 & $\mathrm{~mW}$ \\
\hline 7 & Lenovo Vibez2 & Li ion & 3000 & mAh & 408 & h & 30 & h & 7.35 & $\mathrm{~mA}$ & 100.00 & $\mathrm{~mA}$ & 3.7 & V & 27.21 & $\mathrm{~mW}$ & 370.00 & $\mathrm{~mW}$ \\
\hline 8 & LG K10 & Liion & 2300 & $\mathrm{mAh}$ & 100 & h & 4 & h & 23.00 & $\mathrm{~mA}$ & 575.00 & $\mathrm{~mA}$ & 3.7 & V & 85.10 & $\mathrm{~mW}$ & 2127.50 & $\mathrm{~mW}$ \\
\hline 9 & Noir E8 & Li ion & 3520 & mAh & 437 & h & 39 & h & 8.05 & $\mathrm{~mA}$ & 90.26 & $\mathrm{~mA}$ & 3.7 & V & 29.80 & $\mathrm{~mW}$ & 333.95 & $\mathrm{~mW}$ \\
\hline 10 & Infinix Hot 3 & Li Poly & 3000 & mAh & 230 & h & 20 & h & 13.04 & $\mathrm{~mA}$ & 150.00 & $\mathrm{~mA}$ & 3.7 & V & 48.26 & $\mathrm{~mW}$ & 555.00 & $\mathrm{~mW}$ \\
\hline
\end{tabular}

2. Figure. Power during Standby \& Talk time

\section{References}

[1] Karthik, B.G.; Shivaraman, S.; Aditya, V., Wi-Pie: Energy Harvesting in Mobile Electronic Devices, Global Humanitarian Technology Conference (GHTC), 2011 IEEE, Page(s): 398 - 401, 2011.

[2] Qutaiba, I.Ali: Design and Implementation of a Mobile Phone Charging System Based on Solar Energy Harvesting, Iraq J. Electrical and Electronic Engineering, 2011, Volume:7, Issue: 1, Page(s): $69-72,2011$.

[3] Chung, I.Y.W.; Liang, Y.C.: A low-cost photovoltaic energy harvesting circuit for portable devices, Power Electronics and Drive Systems (PEDS), 2011 IEEE Ninth International Conference, Page(s): 334 - 339, 2011.

[4] Sojan, S.; Kulkarni, R.K.: A Comprehensive Review of Energy Harvesting Techniques and its Potential Applications, International Journal of Computer Applications (0975 - 8887), Volume 139- No.3, Page(s): 14-19, 2016.

[5] Linqiang, L.; Dahu, W.; Tong, Z.; Mingke, H.: A Manual Mobile Phone Charger, Electrical and Control Engineering (ICECE), 2010, Page(s): 79 - 82, 2010.

[6] Wei, C.K.; Ramasamy,G.: A Hybrid Energy Harvesting System for Small Battery Powered Application, Conference on Sustainable Utilization and Development in
Engineering and Technology(STUDENT), IEEE 2011, Page(s): 165 - 170, 2011.

[7] Dai, D.; Liu, J.: Design of a Practical Human-Powered Contactless Charger for Cellphone, IEEE Transactions on Consumer Electronics, Volume: 59, Issue: 3, August 2013, IEEE, Page(s): 476 - 482, 2013.

[8] Raavi, S.; Arigong, B.; Zhou, R.; Jung, S.; Jin, M.; Zhang, H.; Kim, H.: An Optical Wireless Power Transfer System for Rapid Charging, Wireless and Microwave Circuits and Systems(WMCS), 2013, Page(s): $1-4$, 2013.

[9] Park, S.; Koh, B.; Wang, Y.; Jaemin, K.; Kim, Y.; Pedram, M.; Chang, N.: Maximum Power Transfer Tracking in a Solar USB Charger for Smartphones, Symposium on Low Power Electronics and Design,IEEE 2013,Page(s): 88 - 93, 2013.

[10] Aga, N.; Agasimani, N.; Chandralekha, D.; Bhushanagoudra.; Pawar, A.; Naduvinamani, S.: Review on Energy Harvesting Sources, Proceedings of NCRIET- 2015 Indian J.Sci.Res., 2015.

[11] Din,N.M.;Chakrabarty,C.K.;Ismail,A.B.;De vi,K.K.;Chen,W.Y.: Design of RF Energy Harvesting System for Energizing Low Power Devices, Progress in Electromagnetic Research, Volume:132, 2012, Page(s): 49-69, 2012 